\title{
INTERNAL CONTROL ACTIVITIES: CAUSE AND EFFECT OF A GOOD GOVERNANCE OF ACCOUNTING REPORTINGS AND FISCAL DECLARATIONS
}

\author{
Tatiana Dănescu ${ }^{l}$, \\ Mihaela Prozan ${ }^{2}$ \\ Andreea Cristina Dănescu ${ }^{3}$
}

\begin{abstract}
As a subsystem of the management system, the internal control could be viewed as the primordial condition for the efficient and effective accomplishment of the general and specific objectives of any organization. From the audit perspective, the internal control represents both an objective of the internal auditor activity, and a means to achieve a goal for the external auditor. Starting from these approaches and from the perspective of the impact towards the corporative governance, the qualitative analysis of the internal control, is a current and complex issue. Hence, the scientific research has been focused on identifying the answers for the following questions: Could risks that refer to the administrating of state revenues be controlled until a reasonable level? In the given context, which is the role of the internal control activities in achieving a good corporate governance in entities - taxpayers?
\end{abstract}

Key words: corporate governance, internal control activities, risk strategy, risk tolerance, state revenues` management

JEL codes: $M 42, G 28, G 38$

\section{Introduction}

The existence of a public administration which is modern, flexible, performant and adapted to the requirements of taxpayers represents an essential requirement in achieving the objectives afferent to the activity of state revenues administration. However, this requirement supposes the existence of an adequate internal control not only at the level of the entities that administrate state revenues, but also at the level of each private of public entity which is a taxpayer - supplier of the information of fiscal obligations through the accounting and fiscal reporting.

Depending on risk tolerance, the practice has proven that an absolute approach towards risks is not possible; therefore the risk controlling problem is treated, most often, in a relative way. Hence, due to the complexity of the approached topic, the paper considers mainly the way in which public entities form the analyzed area dispose of adequate internal control activities and also the way through which the entities - taxpayers apply a corporative governance that refer to the credibility and the transparency of accounting reports and of fiscal declarations.

\footnotetext{
1 “Petru Maior” University of Tîrgu Mureş, Romania,e-mail: tatiana_danescu@yahoo.com

2 "1 Decembrie 1918" University of Alba Iulia, Romania, e-mail: Mihaela.Prozan@yahoo.com

3 "1Decembrie 1918" University of Alba Iulia, Romania,e-mail: andreea_danescu@yahoo.com
} 


\section{practice \\ An approach towards the internal activities in the literature, in regulations and in}

The internal control represents a set of policies, measures and procedures designed and implemented by the responsible entity at all levels in order to provide reasonable assurance to achieve its objectives in an economic, effective and efficient way. Thus, it is involved in achieving an overall objective resulting in the continuity of the entity in achieving s goals. These ones can be divided in turn into several objectives: security of assets, quality of information, such directives, optimizing the resources (The internal audit regulation 2120 - 2120.A1, "The Control")

In relation to the pursued objectives, for a proper implementation of the internal control, there emerged a number of models, consisting generally of defining control, control criteria and grouping them in accordance to certain rationalities. In the literature, in regulations on internal control and in audit, the most known international practice internal control models are: COSO, CoCo (recommendations on internal control - The new statement of internal control practice), the model outlined by the International Standard on Auditing (ISA) 315.

Starting from the premise that, in state revenues management, the internal control is essential in achieving the objectives of an efficient collection of tax claims, which is based on considerations identified in the literature and in regulations, and also in the research performed in several entities, there was developed a public model adapted to the specific internal control in this area (Briciu Sorin, Danescu Tatiana, Prozan Mihaela Andreea Danescu, 2011, "Model of Internal Control in the Management of State Revenues", WSEAS Conference Iasi).

The comparative analysis showed that the listed models are all made up of a number of five elements, but also that they show some differences in terms of components name, features and their structural arrangement. Therefore, to control risks or rather in response to risks identified and assessed through performance management in each of these, there was created a component named „,control activities”(Table no 1)

Table no 1

Control activities, element of the internal control activities

\begin{tabular}{|l|l|l|l|}
\hline COSO Model & ISA 315 Model & $\begin{array}{l}\text { OMFP 946/2005 } \\
\text { Model }\end{array}$ & $\begin{array}{l}\text { Administrating entities } \\
\text { Model }\end{array}$ \\
\hline Control activities & $\begin{array}{l}\text { Relevant control } \\
\text { activities for audit }\end{array}$ & Control activities & Control activities \\
\hline
\end{tabular}

Source: The comparative research conducted by the authors

In the literature and in the regulatory requirements, the notion of "control activities" is common also under other names such as "policies and procedures for segregation of duties (tasks), proper authorization of activities, taking information in documents, accounting physical checks on the account assets and documents ....." (Tatiana Danescu, 2007: 230), "specific devices" (Jacques Renard, 2003: 134), "internal control mechanisms" (Arens Loebbecke, 2003: 332) "procedures, internal control mechanisms and devices" (Ion Oprean, SA, 2007: 42)," internal control devices and instruments" (MFP, 2007: 65), "policies and procedures that support performance management instructions" (Ana Morariu, SA, 2008:75) and so forth. Although the terminology used in defining this concept is varied, it can be concluded that, in terms of the role, scope and the objectives, the terms of use do not differ substantially, each trying to cover this concept as well as possible. Thus, by extension, internal control activities can be defined as "policies, procedures, mechanisms, devices and instruments" specific to each entity, activity or operation, developed and implemented for the effective management of the identified risks performance.

Thus, in the frame of any entity, controlling the risks involves the implementation of internal control activities that would lead either to mitigate the likelihood of identified risks to materialize, or to reduce the impact of these or even to act upon both components. 


\section{Research Methodology}

Addressing how to control specific risk management activities is aimed at presenting the importance, role and place that adequate internal control activities have within the internal control system as a response to identified risks. On the other hand there was analyzed how this component provides a basic condition of good corporate governance of taxpayers through the tax and accounting reporting.

In this regard it was used a constructive methodology with a step by step application process in the frame of the Public Finance General Directorate Mures with a localization specifically in the subordinated fiscal units ( 7 administrations in Mures county), at the state revenues administration processes of circa 151000 taxpayers (natural and legal persons) and in the frame of entities taxpayers which carry out accounting reports. Thus, the study developed is based on two questionnaires, one on the assessment of internal control, in particular of internal control activities within the public entities analyzed, and the other questionnaire focuses on the impact of this component of internal control over reporting accounting and tax of 35 medium and small taxpayers.

Also, the approach of objectifying the data has considered the antithesis and the synthesis of ideas on how to control risks, found in the literature and in industry regulations.

In this context, the identification and definition of new models and methodologies for internal control in accordance with the continuously changing reality will bring value added both for the management of state revenues and for the entities - taxpayers and the involved beneficiaries such as managers, shareholders, employees, authorities, internal and external auditors, etc..

\section{The internal control activities in the management of state revenues in Romania}

Since we refer primarily to internal control of public entities that have as their object of activity the administration of state revenues is essential to begin to clarify some of the basic features of this activity.

The administration of state`s income refers to all activities of tax authorities in connection with: tax registration, declaration, assessment, verification and collection of taxes, contributions and other amounts owed to the general consolidated budget, tax appeals against administrative acts (Government Ordinance nr.92/2003). In carrying out these activities, an important role is to create an inventory tax with a high degree of certainty and availability based on the information on tax returns and accounting reports of entities-taxpayers.

In 2005, in order to harmonize the legislation with the acquis communautaire in the field of internal control, there was issued the "Internal Control Code", a document which was approved as an internal control model for public entities (Order no. 946/2005). Thus, in the frame of the National Revenue Agency and its subordinate entities, the development of the internal control and the management system was initiated in 2006-2007 through the implementation of this code (Order no. 344/2006, Order nr.711/2007 Decisions No .504/2007, nr.251/2008 and nr.567/2011), according to a program that contains 11 stages, out of which nine are completed and two are still being implemented (Court of Auditors, Audit Report, 2011).

The internal control model includes components of both the internal control and of management, which in turn include a number of standards that define the minimum rules of management and control. For example, for the implementation and the evaluation of the component "control activities" there have been developed seven standards, each of them having a minimum set of criteria associated with legal references analyzed (table no. 2). 
Table no. 2

The way of implementing control activities - control and management standards of the analyzed entities

\begin{tabular}{|c|c|c|}
\hline $\begin{array}{l}\text { Name of the } \\
\text { standards }\end{array}$ & $\begin{array}{l}\text { Implemented-I/ } \\
\text { Partially } \\
\text { implemented- } \\
\text { PI/ Not } \\
\text { implemented-N }\end{array}$ & The way of implementing the standards \\
\hline $\begin{array}{l}\text { Standard } 17 \\
\text { Procedures }\end{array}$ & $\mathrm{I} / \mathrm{PI}$ & $\begin{array}{l}\text { For the majority of carried activities there are formalized } \\
\text { procedures and for specific activities these are comprised in } \\
\text { procedure manuals. Generally, the procedures are clear, } \\
\text { accessible, available, known and applied. Currently, they are in } \\
\text { an updating process of - form and content. }\end{array}$ \\
\hline $\begin{array}{l}\text { Standard } 18 \\
\text { Attributions } \\
\text { separation }\end{array}$ & I & $\begin{array}{l}\text { According to the organigrams and the organizing rules, there is } \\
\text { insured the segregation of initiating, verifying and approving } \\
\text { operations and attributions. }\end{array}$ \\
\hline $\begin{array}{l}\text { Standard19 } \\
\text { Supervision }\end{array}$ & I & $\begin{array}{l}\text { According to the established competences, the management } \\
\text { from all levels insures the supervision and the approval of the } \\
\text { performed operations and of the issued documents in the frame } \\
\text { of the administrating processes. }\end{array}$ \\
\hline $\begin{array}{l}\text { Standard } 20 \\
\text { ABETERILE } \\
\text { Administering }\end{array}$ & $\mathrm{I}$ & $\begin{array}{l}\text { Through the monitoring activities there are identified the } \\
\text { divergences from the planed objectives; depending on the causes } \\
\text { and circumstances that determined them, the implemented } \\
\text { control activities are revised. }\end{array}$ \\
\hline $\begin{array}{l}\text { Standard } 21 \\
\text { The } \\
\text { continuity of } \\
\text { the activity }\end{array}$ & I & $\begin{array}{l}\text { As a consequence of the internal control activities } \\
\text { implementation, there were not identified operations that imply } \\
\text { a high degree of risk exposure, in this way it is created the } \\
\text { continuity of the activity, also there were inventoried the events } \\
\text { which could affect the continuity of the activity and it was } \\
\text { elaborated a procedure for administering them. }\end{array}$ \\
\hline $\begin{array}{l}\text { Standard } 22 \\
\text { Control } \\
\text { strategies }\end{array}$ & I & $\begin{array}{l}\text { According to the inherent risks of the state revenue } \\
\text { administering activities there are implemented control strategies } \\
\text { through which the residual risks are maintained at a reasonable } \\
\text { level reported to the established level of tolerance }\end{array}$ \\
\hline $\begin{array}{l}\text { Standard } 23 \\
\text { Access to } \\
\text { resources }\end{array}$ & $\mathrm{I}$ & $\begin{array}{l}\text { With some exceptions, it is insured a reasonable access at } \\
\text { resources fir the accomplishment of the established objectives in } \\
\text { performing conditions. }\end{array}$ \\
\hline
\end{tabular}

Source: The research conducted by the authors

In theory, from the content of the standards set out it is shown, in the sense of this model, that there are considered internal control activities or content of this component part of the procedures, supervision and organization, and the overall objective of internal controls resulted in business continuity and one of the fundamental principles of internal control - segregation of duties respectively. Also, through the control function, the management establishes and manages deviations from the set objectives, analyzes the causes and circumstances that generated them, based on preventive or corrective measures imposed by the situation analyzed. To achieve these goals, depending on access to resources, the public entities base their work on considering appropriate management strategies for achieving their goals.

As shown also by the legislative act through which they were approved, the internal control and the management standards are formulated in a general way stating that managers can adapt and 
develop according to the specific legal, organizational, financing, cultural, personal, etc. of each activity separately. However, difficulties in applying the standards in practice lead to the idea that they do not contain sufficient criteria necessary for the implementation and evaluation and information on all types of internal control activities that can be applied to public entities, depending on their general risks.

In the analyzed entities the internal control could be noticed under several forms: selfcontrol, control and hierarchical control chain. Thus, there are implemented the following internal control activities: observation, verification, examination, review, analysis, comparison, authorization, approval, reporting, coordination, supervision, segregation of duties, supervision, monitoring.

Given that most processes are computerized, besides the internal control activities that are based on manuals, the management of state revenues disposes of many IT controls in the frame of the used applications in administering the taxpayers. Therefore, ensuring fiscal records in accordance with the information from the taxpayers, as the decision factor administration generator, requires appropriate controls in terms of management information system of tax claims. In this sense, in the frame of the entities - there are several controls considered as the general IT controls that ensure reasonable functioning of computer applications related to controls.

The objectives in terms of performance, confirmed by the positive performance indicators in the period 2007-2010 (Court of Auditors, Audit Report, 2011), show that overall the management of the public entities proactively registered remarkable progress in the internal control system issues. However, there are some failures, arising from the implementation of inadequate internal control activities related to some domain-specific risk analysis activities or in some cases from the lack of computer applications needed for adequate control of operations.

\section{Internal control activities - an answer to the specific risks of state's revenues administration}

\section{Typology and Characteristics of internal control activities}

The culture, the specific of each entity - taxpayer and the risk environment, affect the internal control activities; so whatever their nature, they must be formalized by internal documents of each public entity managing state revenues, making they useful and viable for the internal control. In this respect, it is necessary that the specific internal control activities meet certain requirements that are:

- established as an essential component of the internal control system;

- synchronized to control the risks identified in the risk strategy adopted;

- integrated into the organization;

- established and defined for each activity, operation, process in part;

- simple, complete, clear, accurate and tailored to the specific public entity;

- reviewed and updated regularly depending on the risks identified;

- known, understood and applied correctly by the staff involved.

Although each of the actions arising from the application of decisions is important, research has focused only on identifying ways to achieve the treatment of risks that can not be tolerated, respectively on the control of the most significant risks in the management of state revenues in terms of the consequences of their materialization. In this context, depending on the nature of the risks identified, the risk treatment requires the adoption and implementation of policies and procedures, respectively of some specific control mechanisms, which particularized in the frame of the state revenue administration activity could be shown synthetically in table no. 3 
Table no. 3

Grouping the control activities according to the nature of the treated risks

\begin{tabular}{|l|l|}
\hline Group & Internal control activities \\
\hline Objectives & $\begin{array}{l}\text { Impose the establishment of general objectives synchronized with the entity's } \\
\text { mission, transposed in specific objectives for the state revenues administration, } \\
\text { which in order to give coherence to the internal control have to be: precise, } \\
\text { measurable verifiable, realistic with clear terms of achievement; }\end{array}$ \\
\hline Means & $\begin{array}{l}\text { The existence of some inconsistencies between the resources and the followed } \\
\text { objectives represents one of the most common circumstances which favors the } \\
\text { appearance of several risks, hence it is necessary to ensure the adequacy of both the } \\
\text { quantitative and qualitative means (human, material, financial resources etc.) of the } \\
\text { entity. }\end{array}$ \\
\hline $\begin{array}{l}\text { Information } \\
\text { systems }\end{array}$ & $\begin{array}{l}\text { The transparency has to be a ground rule - this implies to know the risks through } \\
\text { good communication; therefore, the operative clear and precise diffusion of the } \\
\text { information to the users imposes the existence of an adequate It system for the } \\
\text { administering of the state revenues; }\end{array}$ \\
\hline Organization & $\begin{array}{l}\text { Together with other well-known organizing principles, the elimination of the } \\
\text { inadequacies from the structural or procedural organization supposes the strict } \\
\text { application of the principle of attribution segregation in accordance with some strict } \\
\text { criteria reported to the identified risks: in this case it is imposed the identifying of } \\
\text { the sensible functions; }\end{array}$ \\
\hline Procedures & $\begin{array}{l}\text { Controlling the risks and the circumstances generated by the way of conducting the } \\
\text { work processes imposes the elaboration of formalized procedures for all the } \\
\text { activities, operations and processes from the state revenues administering, which in } \\
\text { order to be useful have to be: clear, simple, easy to understand and to apply, } \\
\text { permanently updated, known by the entire personnel; }\end{array}$ \\
\hline Supervision & $\begin{array}{l}\text { It deals with the treatment of risks generated by the non-corresponding supervision } \\
\text { of the state administering activities caused by an inadequate style of management; } \\
\text { therefore, the supervision refers to all the processes and supposes the coordination, } \\
\text { motivation and corresponding verification in order for the personnel to be conscious } \\
\text { that the activity that they perform is supervised. }\end{array}$ \\
\hline
\end{tabular}

Source: Adaptation of the internal control activities after the work: "The theory and practice of internal audit" (Jacques Renard, 2002: 144)

Grouping control activities highlights the links between them and other components of the internal control system of managing state's revenues, which influence and reinforce each condition. For example, the internal control environment has an impact on internal control activities concerning the means and organization, the ones related to the objectives are connected through the risk management to the control activities, a good communication is provided through the information system, and the supervision procedures ensure smooth running of activities in monitoring their impact. Along with the management, periodically on the results of independent risk assessment, the internal audit evaluates the adequacy and effectiveness considering the internal control activities.

To ensure the transparency and the credibility of reporting accounting information by reducing the risks associated with a particular impact in the fiscal accounts, in a pragmatic and effective internal control activity there are policies and procedures that ensure: segregation of duties, proper authorization of activities; retrieving information in documents, records, physical inspections of assets accounting, accounting documents, verifying the procedures and results (Tatiana Danescu, 2007: 230-235).

Thus, entities - the taxpayer must implement adequate controls or optimal combination of 
control activities in the development of information flows necessary for compiling accounting reports and tax returns required for the records conducted by the entities - the taxpayer, on the one hand, and on the other hand, the competent tax authorities in their management. Therefore, internal control activities have a key role in ensuring the reliability and credibility of accounting information relating to claims and tax liabilities of the accounting reports impact of the efficiency of state revenues administration.

\section{Hypotheses for the internal control activities implementation}

In order to sustain an adequate risk strategy, a fundamental role is played by the establishment of a proper attitude towards the identified and assessed risks, determined by reporting the level of risk exposure to the tolerance level defined, declared and accepted. On this basis, any entity - taxpayer has to establish the most appropriate internal control activities and circumstances for each risk (Table 4).

Table no. 4

The relationship between the risk management and the control activities according to the attitudes towards risk

\begin{tabular}{|c|c|c|l|}
\hline EXPOSURE & TOLERANCE & $\begin{array}{l}\text { ATTITUDE } \\
\text { TOWARDS } \\
\text { RISK }\end{array}$ & CONTROL ACTIVITIES \\
\hline Low & High & Accepting & $\begin{array}{l}\text { There are not imposed activities of internal } \\
\text { control }\end{array}$ \\
\hline Moderate & Acceptable & Monitoring & The evaluated risks are supervised \\
\hline Average & Small & $\begin{array}{c}\text { Elimination of } \\
\text { circumstances or } \\
\text { treatment }\end{array}$ & $\begin{array}{l}\text { The elimination of the causes which } \\
\text { determine the risks materialization or } \\
\text { implementing a control activity }\end{array}$ \\
\hline High & Low & Treatment & Implementing adequate control activities \\
\hline Critical & Unacceptable & Treatment & Implementing adequate control activities \\
\hline
\end{tabular}

Source: The comparative research conducted by the authors on the base of specialty literature and

The data presented shows that, depending on the level of exposure and tolerance, the attitudes towards risk may result in the acceptance, monitoring and treating of the risk and in some cases in eliminating the circumstances. Experience has confirmed that there are risks that can not be controlled at an appropriate level or even some that are uncontrolled. This situation is one where the achievement is affected by some external risks (legal framework, economic environment etc.), for which domestic entities do not have internal control instruments, therefore, the most appropriate solution for this type of problems is their outsourcing.

Compared to the situation presented in the COSO optics, there are four types of risk responses (acceptance, avoidance, sharing, reduction), depending on the circumstances most of the entities combine them (William Sun, SA, 2011:232).

According to the previous reasoning, the relationship between risk management and internal control activities are carried out through the risk strategy addressed (fig.nr.1). 


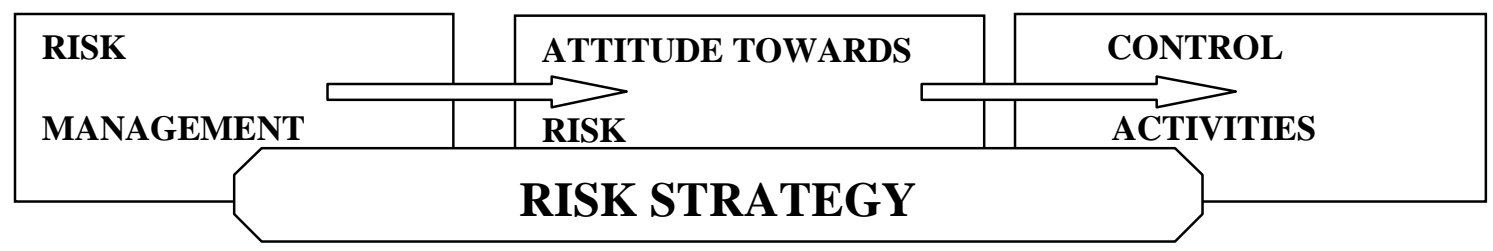

Fig. no. 1 - The relationship between the risk management and the control activities according to the attitudes towards risk

Source: Authors`interpretation

Therefore, if the inherent risk exposure is higher than the risk tolerance limits set by the management, in order for the residual risk to have an exposure to risk equal to the maximum allowed tolerance level there is necessary to implement adequate internal control measures (formula No. 1).

$$
\text { RE - > RT -> CA -> RS }
$$

Formula no. 1 The relationship between the risk exposure, the risk tolerance, the control activities and the risk strategy

Source: The research conducted by the authors based on the specialty literature and on practice

In which: RE - risk exposure, RT - risk tolerance, $\mathrm{CA}$ - control activities imposed for risk treatment and RS - risk strategy.

Taking into account the mechanism shown, in the case of the entity analyzed, according to the information compiled in the Risk Register DGFP Mures what is relevant is the implementation of the risk management process and implementation of internal control (table no. 5).

Table no. 5

The results of implementing standard 11:"Risk Management" and the strategy adopted towards the identified risks

\begin{tabular}{|l|l|l|l|l|l|l|l|l|}
\hline $\begin{array}{l}\text { No. } \\
\text { Identified } \\
\text { risks }\end{array}$ & $\begin{array}{l}\text { No. } \\
\text { Classified } \\
\text { risks }\end{array}$ & $\begin{array}{l}\text { No. } \\
\text { Evaluated } \\
\text { risks }\end{array}$ & $\begin{array}{l}\text { No. } \\
\text { Tolerated } \\
\text { risks }\end{array}$ & $\begin{array}{l}\text { No. } \\
\text { Supervised } \\
\text { risks }\end{array}$ & $\begin{array}{l}\text { No. Risks - } \\
\text { eliminating } \\
\text { the } \\
\text { circumstances }\end{array}$ & $\begin{array}{l}\text { No. } \\
\text { Treated } \\
\text { risks }\end{array}$ & $\begin{array}{l}\text { No. } \\
\text { Transferred } \\
\text { risks }\end{array}$ & $\begin{array}{l}\text { Internal } \\
\text { control } \\
\text { activities }\end{array}$ \\
\hline 226 & 153 & 73 & 25 & 29 & 3 & 10 & 6 & 10 \\
\hline
\end{tabular}

Source: The research conducted by the authors

The data presented shows that only $32.30 \%$ of the identified risks have been assessed because the rest were judged to be negligible, and of these $13.69 \%$ the treatment was imposed by applying additional internal control activities suitable for each case, given both the skills and resources ordering. Thus, the risks of the administration of the state`s income are controlled to a reasonable level to achieve the objectives.

Compared to the situation shown, approximately $80 \%$ of the surveyed taxpayers have not implemented formalized adequate risk management processes, but in their opinion they have established control activities to respond to a reasonable risk that could affect the reliability of information on tax liabilities of tax returns and accounting reports.

Given the importance of accounting reports and tax returns for the achievement of performance of the state revenue administration, in the situation in which entities - taxpayers have appropriate policies and procedures to ensure real information on tax obligations and entitlements, 
they will be reflected accurately in the fiscal accounts and generate benefits for the implicated parties and also for third parties. Otherwise, the implementation of inadequate activities can be the cause of some wrong decisions with direct implications through the risks assumed (future tax burden) and in terms of usefulness and reliability of the information presented to the user concerned. Therefore, without considering the state as a privileged user, we believe that the negative effects will be reflected also in the management of state revenues, directly materialized in not knowing the real value of the tax claims which will reflect in the planning and budgetary execution, and in increasing administrative costs.

Also, internal control activities of public entities can affect the management policies and procedures implemented by the taxpayers.

\title{
3 The cost benefit analysis in selecting the internal control activities
}

From practical reasons, but also from the perspective of the performance of internal control, the research highlighted the importance of proper choice of control activities in response to the identified risks, the relevant scenarios being:

$>$ If the risk management process is affected by errors due to human reasoning or to other reasons (inadequate attitude of those involved), the exposure level and risk tolerance level are distorted, and hence the attitude towards these risks is inappropriate. In such cases, situations may arise when: it is poorly quantified one or both elements of risk assessment (likelihood and impact); are identified and assessed imaginary risks (fiction), etc.., thus affecting the actual level of exposure with direct consequences in the approach of attitude towards these. For example, in the activity of the collection of tax claims, if we analyze the prescribing risk of the right of the fiscal body to seek enforcement and the risk assessment of exposure of that entity is less than the real one, by reference to risk tolerance, there can result cases when these are accepted or supervised even though in the given situations the appropriate solution would have been the imposing of operational control actions.. If the amount of tax claims covered by this risk is significant, the materialization of a risk would severely affect one of the set objectives, meaning the amount of revenue and thus the achievement of budgetary execution .

$>$ The response decisions to the assessed risks and the establishing of appropriate control activities can be affected by the subjectivity of human reasoning and the default of the risk strategy. To avoid such problems, assuming that the entity has adequate risk management, it is necessary that the actions that will be taken, to be based on a cost-benefit analysis in which two aspects to be analyzed:

- The costs concerning the control activities which are imposed reported to the cost of the risk materialization;

- The costs of the varied control activities in order to set the most adequate control action from the efficiency point of view;

As a consequence, again there are high lightened the connections that exist between the internal control components, respectively the risk strategy foundation will take into consideration the implied costs (formula no. 2 and formula no. 3).

\section{CER $>=\mathrm{AC} \rightarrow \mathrm{CA}$}

Formula no. 2: The analysis of the costs implicated in the control activities implementation Source: The research conducted by the authors

In which: REC - risk exposure cost, $\mathrm{CA}$ - control activities cost, $\mathrm{CA}$ - control activities.

\author{
CAS $<=$ PCA1 $>=$ PCA2 $>=\ldots .$. PCAn $\rightarrow$ RS \\ Formula no. 3: Establishing the control activities depending on the costs implied \\ Source: The research conducted by the authors
}


In which: CAS - control of cost established for the risk treatment activity, PCA - potential cost control activities, RS - risk strategy.

Therefore, for the success of this process, the entities have to dispose of a rational and performant risk management and of adequate control strategies concretized in the value added.

\section{Conclusions}

The existence of an adequate internal control system in the state revenues administration supposes that, nearby the other elements of the internal control which participate at the accomplishment of the set objectives, efficient and effective internal control activities as a response to the identified risks to exist. This thing is possible through the defining of a mechanism of internal control implementation as a result of the risk management process in the frame of the risk strategy establishment. Hence, it is implied that in accordance with the risk exposure it is established the risk profile of the entities from the analyzed activity, and reported to the level of tolerance admitted the risk strategy will be determined.

The treatment of the risks could be considered the response strategy towards risk which insures the best the continuity of the activity of state`s revenues administration, with the condition that the internal control activities implemented to be correctly defined reported to the specific risks that have to be controlled. As a consequence, the functionality and the synchronization of the control activities with the other activities of the system are shown through their grouping in function of their nature.

Also, in all the cases it is imposed that previously to the establishment of the control mechanisms to be conducted a cost benefit analysis. The decision upon an adequate risk strategy could have as a result an added value, through the insuring of a feasible fiscal reporting concerning the real quantum of the administrated tax claims, with an impact in the increase of state's revenues and the decrease of the administrative costs.

In conclusion, we consider that the elaboration and the implementation of some adequate internal control activities as a response to the specific risks of state's revenues administration activity, will assure the control of risks until a reasonable level, which will in return lead to a good corporative governance in the analyzed entities.

\section{References}

1. Arens L, 2003. Audit - an integrated approach, the 8th edition, Publishing House ARC, Chişinău, pp 332.

2. Briciu S., Dănescu A., Dănescu T., Prozan M., 2011. Internal control model in the state`s revenues administration", article presented at the Conference- WSEAS and IAASAT Conferences, Iasi.

3. Danescu T., 2007. Financial Audit - convergences between theory and practice, Irecson Publishing House, pp.230 -284.

4. Jinga C.G., 2009. Financial audit, ASE Publishing House, Bucureşti, pp. 166.

5. Morariu A., Suciu G., Stoian F., 2008. Internal Audit and Corporative Governance, Universitară Publishing House, Bucureşti, pp. 32-33.

6. Oprean I, Popa I.E., Radu D., 2007. Audit and Financial Control Procedures, Risoprint Publishing House, Cluj Napoca, pp. 42.

7. Renard J., 2002. Internal Audit Theory and Practice, M.F.P., pp. 134-144.

8. Sun W., Stewart J., Pollard D., 2011. Corporate Governance and the Global Financial Crisis: International Perspectives, Cambridge University Press, pp. 232.

9. Government Ordinance nr. 92/2003 regarding the fiscal procedure code. 
10. Public Finances Minister Order nr. 946/2005 regarding the internal control Code, comprising the management/control standards at the public entities, 5 July.

11. ANAF Order ANAF 344/2006 and ANAF Order nr.711/2007.

12. The DGFP Mures executive director's decisions nr.504/2007, nr.251-2008 and nr.567-2011.

13. International Audit Standards Manual, 2009 - The International Audit Standard 315 - The identification and the evaluation of the risks of significant denaturalization through understanding the entity and its environment

14. The Internal Audit Norm 2120-2120.A1, „The Control”, available at: www.aair.ro/new3/fisiere/standarde-romana/Standarde_IIA_rom.pdf;

15. Recommendations regarding the internal control - extract from the New Prcatice of the Internal Control (COSO 1985 and COCO 1995), The Romanian Public Finance Minister, 2004, pp.13-42.

16. Methodological support for the internal control development in public entities, The Romanian Public Finance Minister, the Central Unity of Harmonizing the Systems of Financial Management, pp. 4.

17. The methodology for implementing the internal control standard "Risk Management", The Romanian Public Finance Minister, the Central Unity of Harmonizing the Systems of Financial, 2007, pp. 65.

18. Audit report, The performance audit concerning the collection of taxes of the public budget, DGFP Mureş, from 30.05.2011.

19. The Risk Register at the level of DGFP Mureş as a consequence of the implementation of the internal control and management standard 11 "Risk management". 